Article

\title{
Temperature Effects on the Growth Rates and Photosynthetic Activities of Symbiodinium Cells
}

\section{Widiastuti Karim $^{1, *}$, Sho Nakaema ${ }^{1}$ and Michio Hidaka ${ }^{2}$}

1 Graduate School of Engineering and Science, University of the Ryukyus, Okinawa 903-0213, Japan;

E-Mail: sho.nakaema@gmail.com

2 Faculty of Science, University of the Ryukyus, Okinawa 903-0213, Japan;

E-Mail: hidaka@sci.u-ryukyu.ac.jp

* Author to whom correspondence should be addressed; E-Mail: widiakarim@yahoo.co.id; Tel.: +81-90-8292-1979.

Academic Editor: Loke Ming Chou

Received: 4 May 2015 / Accepted: 25 May 2015 / Published: 1 June 2015

\begin{abstract}
Coral bleaching is caused by environmental stress and susceptibility to bleaching stress varies among types of coral. The physiological properties of the algal symbionts (Symbiodinium spp.), especially extent of damage to PSII and its repair capacity, contribute importantly to this variability in stress susceptibility. The objective of the present study was to investigate the relationship between the growth rates and photosynthetic activities of six cultured strains of Symbiodinium spp. (clades A, B, C, D, and F) at elevated temperature $\left(33^{\circ} \mathrm{C}\right)$. We also observed the recovery of photodamaged-PSII in the presence or absence of a chloroplast protein synthesis inhibitor (lincomycin). The growth rates and photochemical efficiencies of PSII $\left(F_{v} / F_{m}\right)$ decreased in parallel at high temperature in thermally sensitive strains, B-K100 (clade B followed by culture name) and A-Y106, but not in thermally tolerant strains, F-K102 and D-K111. In strains A-KB8 and C-Y103, growth declined markedly at high temperature, but $F_{v} / F_{m}$ decreased only slightly. These strains may reallocate energy from growth to the repair of damaged photosynthetic machineries or protection pathways. Alternatively, since recoveries of photo-damaged PSII at $33{ }^{\circ} \mathrm{C}$ were modest in strains A-KB8 and C-Y103, thermal stressing of other metabolic pathways may have reduced growth rates in these two strains. This possibility should be explored in future research efforts.
\end{abstract}


Keywords: Symbiodinium; growth rate; thermal stress; photodamage; repair mechanism

\section{Introduction}

Symbiotic dinoflagellates of the genus Symbiodinium provide their coral hosts with photosynthetic products that sustain polyp metabolism and growth in oligotrophic waters [1,2]. Environmental stresses, such as elevated seawater temperatures and high irradiances, may disrupt the symbiosis, leading to losses of either Symbiodinium cells or the pigmentation of those within the host tissues; this is the phenomenon of coral bleaching $[3,4]$. The mechanism of coral bleaching is not fully understood. However, it is clear that damage to the algal photosynthetic apparatus may lead to the production of reactive oxygen species (ROS) that cause apoptosis, autophagy, and necrosis of host and algal cells [4-6]. Details of the pathway to cell death depend on the intensity and duration of the environmental stress [4].

Thermal stress has different impacts on the photobiology and growth of diverse phylotypes of cultured Symbiodinium cells [7-11]. The production of reactive oxygen species (ROS) in response to elevated temperature differs among Symbiodinium types [12,13]. Constitutive activity and up-regulation of components of the antioxidant network under thermal stress are different among Symbiodinium types [14]. Thus, variations in the physiological characteristics of Symbiodinium types may be crucial in determining the bleaching susceptibility of coral-algal symbiotic complex, though properties of the host may also influence the bleaching susceptibility of the symbiotic complex $[15,16]$.

Impairment of the Symbiodinium photosynthesis mechanism is most likely the main factor that initiates the coral bleaching. Several hypotheses have been proposed to explain how elevated temperatures affect the photochemical pathway: excessive photon absorption by light harvesting antennae damages the PSII reaction center, particularly the D1 protein [17-19]; elevated temperatures may limit photosynthesis by destabilizing the thylakoid membranes [7]; the activity of Rubisco may be a primary site of damage by elevated temperature [20], though a recent study suggests that inhibition of the Calvin-Benson cycle alone does not induce coral bleaching [21]; damaged PSII reaction centers may be replaced by re-synthesized D1 protein, but this mechanism is inhibited when temperature is elevated [10]; elevated temperatures may also suppress the synthesis of light harvesting antennae protein at the translational step, thereby promoting losses of major light harvesting proteins [9]. Several of these postulates have been supported by recent studies indicating that the thermal stress susceptibility of Symbiodinium is determined by the repair capacity of the photosynthetic mechanism [10,22,23].

Robison and Warner [8] found that growth of A1 phylotype algal symbionts declined significantly with a slight reduction in PSII activity under combined high temperature and high light stress. Growth of B1 algae declined similarly when exposed to high light alone, but PSII efficiency was much reduced. Krämer et al. [24] observed similar differences in growth and PSII responses to combined thermal and light stresses between the clade A subtypes A1 and Ax. They suggested that photosynthesis and growth become uncoupled in A1 cells and that the decline in growth might have resulted from a high energy demand for protein repair and increased respiratory losses. Thus, environmental stress may act on different target processes among the types of Symbiodinium. Growth inhibition may well occur in some of the Symbiodinium types without significant impairment of their PSII efficiencies. Improved 
understanding requires investigation of (i) photosynthesis and growth responses of diverse Symbiodinium types under stress, and (ii) the PSII repair capacity and other metabolic responses of Symbiodinium cells exposed to stresses that cause bleaching.

In the current study, we examined the relationships between growth rate and photosynthetic activity $\left(F_{v} / F_{m}\right)$ in six cultured Symbiodinium spp. strains (clade A, B, C, D, and F) exposed to elevated temperatures. We also investigated the recovery of photodamaged-PSII at high temperature in the presence or absence of a chloroplast protein synthesis inhibitor (lincomycin).

\section{Materials and Methods}

\subsection{Cultures and Growth Conditions}

Six cultures of Symbiodinium spp., belonging to five clades, were used: KB8 (clade A, derived from the jellyfish Cassiopea sp.), Y106 (clade A, from the bivalve Tridacna crocea), K100 (clade B, from the sea anemone Aiptasia pulchella), Y103 (clade C, from the bivalve Fragum sp.), K111 (clade D, from the soft coral Sarcophyton glaucum) and K102 (clade F, originally from the scleractinian coral Montipora verrucosa). The Symbiodinium clades were identified based on 28S rDNA RFLP analysis using the restriction enzyme TaqI. The six cultures will be referred to as A-KB8, A-Y106, B-K100, C-Y103, D-K111, and F-K102 (clade type followed by culture name). Some strains were identified at subclade level based on nucleotide sequence of ITS2 region. These stock cultures had been maintained in $\mathrm{f} / 2$ medium (Sigma-Aldrich, St Louis, MO, USA) at $25{ }^{\circ} \mathrm{C}$ under a photon irradiance of 5-9 $\mu \mathrm{mol}$ photons $\mathrm{m}^{-2} \cdot \mathrm{s}^{-1}$ (12 h light:12 $\mathrm{h}$ dark photoperiod cycle) provided by a white fluorescent lamp (Toshiba FL2022-BRN/18, Fuzhou, China). Cultures were transplanted to a new medium and put into another incubator (LH-70CCFL-CT, NK System, Tokyo, Japan) at the control condition $\left(25{ }^{\circ} \mathrm{C}\right.$, 22-49 $\mu \mathrm{mol}$ photons $\mathrm{m}^{-2} \cdot \mathrm{s}^{-1}$ ) for two weeks before the stress exposure experiment started.

\subsection{Standard Curves of Symbiodinium Cell Densities and in Vivo Chlorophyll Fluorescence}

The growth rate of Symbiodinium cells at different temperatures was measured by changes in in vivo fluorescence. We first established a standard curve for the relationship between Symbiodinium cell density and chlorophyll fluorescence intensity for each strain one day before the stress exposure experiment. The cell densities of stock cultures were measured using a Neubauer improved hemocytometer (Hirschmann, Eberstadt, Germany) under a light microscope (Nikon, Optiphot-2, Tokyo, Japan). A suspension of Symbiodinium cells at known density $\left(2 \times 10^{6}\right.$ cells $\left.\mathrm{mL}^{-1}\right)$ was made up using the hemocytometer, and a series of dilutions (between $1 \times 10^{4}$ and $1 \times 10^{6}$ cells $\mathrm{mL}^{-1}$ ) were prepared. We then measured the chlorophyll $a$ fluorescence intensities of tubes containing various concentrations of Symbiodinium cells using a fluorometer (TD700, Turner Design, Sunnyvale, CA, USA) equipped with excitation $(436 \mathrm{~nm})$ and emission $(680 \mathrm{~nm})$ filters, and a daylight white lamp. The fluorescence intensities were plotted against actual densities of Symbiodinium cells to obtain standard relationships between fluorescence intensity and Symbiodinium cell density. The standard curves were linear in the following range: $1 \times 10^{4}$ to $1 \times 10^{6}$ cells $\mathrm{mL}^{-1}$, which was used in the following experiment. 


\subsection{Growth Rate of Symbiodinium Cells at Different Temperatures}

To compare the physiological responses of the six strains of Symbiodinium, we measured the growth rates of cultured cells of each strain at temperatures of $25^{\circ} \mathrm{C}, 30^{\circ} \mathrm{C}$, and $33{ }^{\circ} \mathrm{C}$ and the photochemical efficiency $\left(F_{v} / F_{m}\right)$ of the algal cells after 14 days of temperature treatment. For each strain, we prepared 12 borosilicate glass tubes ( $10 \mathrm{~mL}$, Fisherbrand, Pittsburgh, PA, USA) filled with $6 \mathrm{~mL}$ of f/2 medium containing Symbiodinium cells at an initial density of $5 \times 10^{4}$ cells $\mathrm{mL}^{-1}$. The 12 tubes were separated into three temperature-treatment groups, which were incubated at $25{ }^{\circ} \mathrm{C}, 30{ }^{\circ} \mathrm{C}$ or $33{ }^{\circ} \mathrm{C}$ in separate incubators (LH-70CCFL-CT, NK System, Tokyo, Japan). The cultures were illuminated by fluorescent lamps (NK System LH-55/70CCFL-CT), which provided a photon irradiance of 22-49 $\mu \mathrm{mol}$ photons $\mathrm{m}^{-2} \cdot \mathrm{s}^{-1}$ (12 h light:12 h dark photoperiod). Each temperature treatment was replicated four-fold. The control tubes contained cell-free filtered seawater subjected to the same treatments. To avoid the effect of different light levels on the growth rate, we moved the position of tubes randomly, everyday during the experimental period.
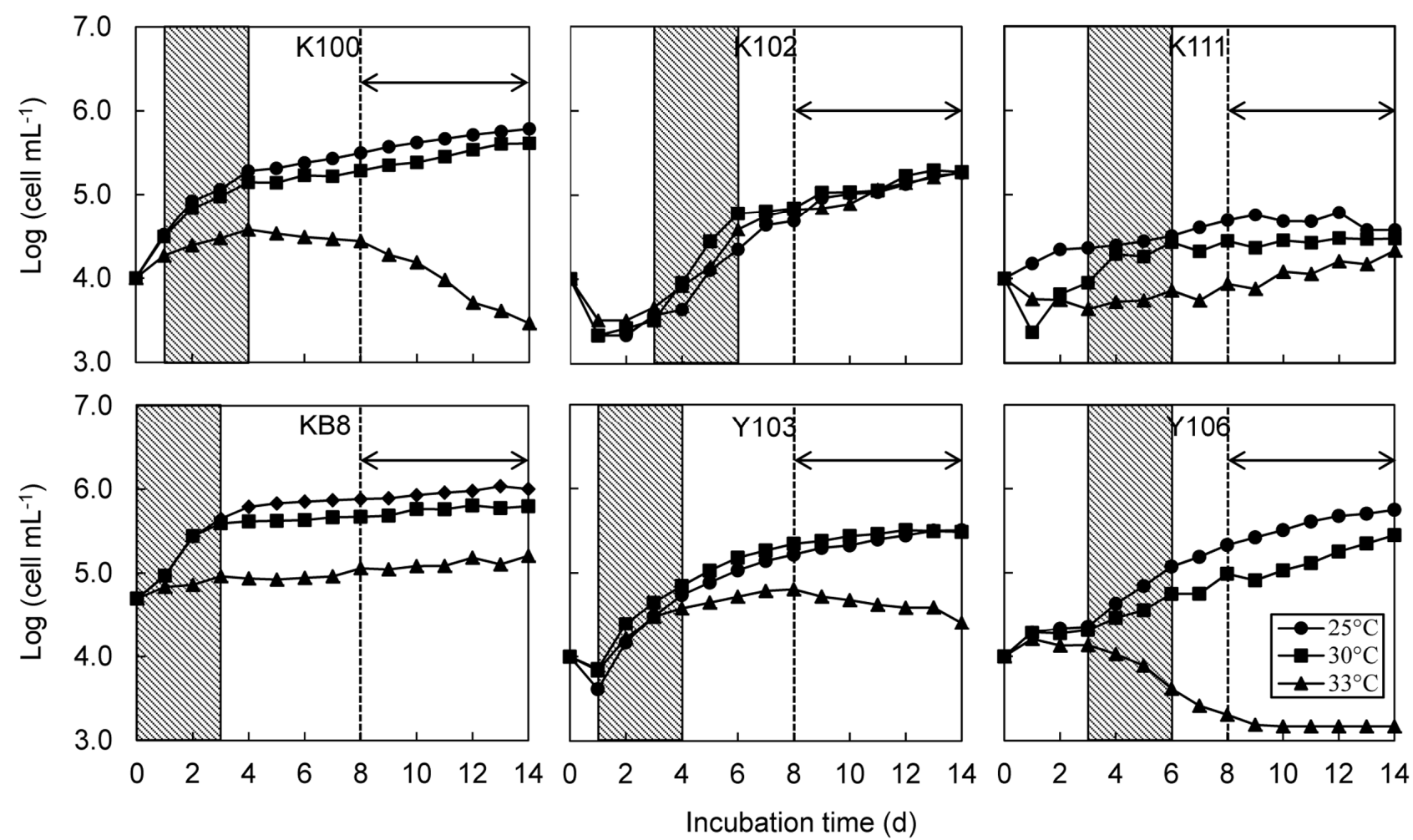

Figure 1. Growth curves of six strains of Symbiodinium at different temperatures. Changes in mean cell density ( $n=4$ for each strain) are plotted over a 14-day period. Shaded areas indicates initial logarithmic phases, which were used for calculations of initial growth rate $(\mu)$. The arrow and dotted line indicate the growth period used for calculation of secondary growth rate $\left(\mu_{\mathrm{s}}\right)$.

The tubes containing Symbiodinium were mixed once daily using a vortex to keep the cells in suspension. We measured fluorescence immediately after vortexing each day for 14 days during the late afternoon (16.00-18.00) using a TD700 fluorometer, thereby circumventing potential effects of a diurnal cell cycle. Cell density was calculated from fluorescence intensity by using the standard curve for each 
strain. The log (cell density) values were plotted against time (days after inoculation) and the growth rate was estimated from the slope of the regression fit in the linear portion of the semi-logarithmic growth curve [25]. The linear portion of the growth curve was selected visually [25]. Log phase growth was linear for 3-5 days; thereafter, growth slowed or plateaued during the stationary phase. High temperature-treated suspensions often had biphasic growth curves; cultures grew linearly at first, but growth became negative after day 8 of the treatment. Thus, we measured an initial growth rate $(\mu)$ based on the initial linear portion of the growth curve (days 1-4 for B-K100 and C-Y103, days 3-6 for F-K102, D-K111 and A-Y106 and days 0-3 for A-KB8), and a secondary growth rate $\left(\mu_{\mathrm{s}}\right)$ based on the later linear portion for days 8 to 14 (Figure 1). Cell density often decreased on the day after inoculation into the experimental tubes. Therefore, cell density data on day 0 were not used for strains other than A-KB8. The initial density drop may have occurred because cells adhered to the bottoms of the tubes after initial inoculation.

\subsection{Measurement of the Photochemical Efficiency of PSII}

The photochemical efficiency of PSII $\left(F_{v} / F_{m}\right)$ was determined at the end of the growth inhibition experiment (day 14). After vortexing, $3 \mathrm{~mL}$ of Symbiodinium cell suspension were removed from each tube using a syringe. The cells were captured on a Millipore filter (13-mm diameter, 0.45 - $\mu \mathrm{m}$ pore size; Millipore, Cork, Ireland). Each filter bearing captured cells was sandwiched between two glass slides held in place with transparent adhesive tape. Cells mounted in this manner were immersed in filtered seawater and dark-adapted for $20 \mathrm{~min}$ in a custom-made acrylic black box at room temperature. We measured $F_{v} / F_{m}$ using a Mini-PAM (pulse-amplitude modulated) fluorometer (Walz, Effeltrich, Germany) (measuring light 8 , saturation pulse intensity 8 , width 0.8 ; gain $=2$ ) [26].

Since cell densities in strains of B-K100 and A-Y106 kept at $33{ }^{\circ} \mathrm{C}$ were too low for measurements of $F_{v} / F_{m}$, we performed an additional experiments to monitor changes in the $F_{v} / F_{m}$ values of strains B-K100 and A-Y106, and C-Y103. We measured cell densities and $F_{v} / F_{m}$ values of these strains at $33{ }^{\circ} \mathrm{C}$ every second day for 12 days. In the additional experiment, we were able to measure $F_{v} / F_{m}$ values without a low signal warning on the Mini-PAM apparatus.

\subsection{Photoinhibition Experiments}

We compared the sensitivity of PSII to light stress and recovery from photodamage among the six Symbiodinium strains at $25{ }^{\circ} \mathrm{C}$ and $33{ }^{\circ} \mathrm{C}$. Cultures were incubated with or without lincomycin, an inhibitor of thylakoid membrane protein synthesis (Wako, Osaka, Japan), to determine the extent to which photodamage and its recovery process depend on re-synthesis of thylakoid membrane proteins, including the D1 protein.

Sixteen $25-\mathrm{mL}$ Falcon cell culture flasks filled with $15-\mathrm{mL}$ f/2 medium containing Symbiodinium cells at a density of $1 \times 10^{6} \mathrm{~mL}^{-1}$ were prepared for each strain. The 16 culture flasks were divided to four groups and exposed to high light $\left(470 \mu \mathrm{mol}\right.$ photons $\left.\mathrm{m}^{-2} \cdot \mathrm{s}^{-1}\right)$ at $25{ }^{\circ} \mathrm{C}$ or $33{ }^{\circ} \mathrm{C}$ in the presence or absence of $200 \mu \mathrm{g} \mathrm{mL}^{-1}$ lincomycin. Each treatment was replicated fourfold. Light was provided by two metal halide lamps ("Funnel 2", Kamihata, Tokyo, Japan), and the temperature was regulated by using waterbaths (WTB, Taitec, Saitama-ken, Japan).

We added $100-\mu \mathrm{L}$ lincomycin to each culture flask in the lincomycin-treatment group (in darkness) $20 \mathrm{~min}$ before exposure to light, thereby making the final concentration $200 \mu \mathrm{g} \mathrm{mL} \mathrm{m}^{-1}$ lincomycin. 
Cultures with or without the inhibitor were subsequently exposed to strong light at $25{ }^{\circ} \mathrm{C}$ or $33{ }^{\circ} \mathrm{C}$ for $2 \mathrm{~h}$. After the light exposure treatment, Symbiodinium cells were transferred to darkness for $1 \mathrm{~h}$ at each temperature, and then allowed to recover under a photon irradiance of $20 \mu \mathrm{mol}$ photons $\mathrm{m}^{-2} \cdot \mathrm{s}^{-1}$ (provided by a ColdSpot, PCS-NHF150, Japan) for $2 \mathrm{~h}$ at each temperature. A new lincomycin dose was added 20 min before the recovery period since the antibiotic may have degraded during the 2-h light exposure treatment [27]. $F_{v} / F_{m}$ values were measured in 1.5-mL samples of Symbiodinium cell suspensions taken from the flasks before and after strong light treatment, and following the recovery period.

\subsection{Statistical Analysis}

Mean growth rates and mean $F_{v} / F_{m}$ values of Symbiodinium cells were compared among treatments using Analysis of Variance (ANOVA) and Tukey's honestly significant difference (HSD) test when the data met requirements of inferential parametric tests. Normality and homogeneity of variances were tested using Kolmogorov-Smirnov and Lilliefors and Levene's tests, respectively. The data were square root and arcsine transformed when necessary. When transformed data did not meet requirements of parametric testing, we used the non-parametric Kruskal-Wallis ANOVA followed by multiple comparisons tests. All statistical analyses were performed using Statistica 6.0 software (StatSoft Inc., Tulsa, OK, USA).

\section{Results}

\subsection{Growth Rates of Symbiodinium Cells at Different Temperatures}

The growth curves varied among strains and among temperature-treatment groups (Figure 1). The shapes of the growth curves at $25^{\circ} \mathrm{C}$ and $30{ }^{\circ} \mathrm{C}$ were similar for each of the six Symbiodinium strains; all had positive growth at these temperatures. Cell densities declined in five strains in the day following inoculation, but were almost constant in A-KB8. Thereafter, growth increased linearly at least for 3-5 days in all cultures. The initial logarithmic phase was followed by a secondary (or stationary) phase with a slower growth rate.

The growth rate at high temperature $\left(33{ }^{\circ} \mathrm{C}\right)$ was lower than those at 25 and $30{ }^{\circ} \mathrm{C}$, except in strain F-K102, which had similar growth curves at all temperatures (Figure 1). Strains A-KB8 and D-K111 had slow but positive growth through the 14-day experimental period, but growth rates of strains B-K100 and C-Y103 fell to negative values after 6-8 days. The growth rate of strain A-Y106 at $33{ }^{\circ} \mathrm{C}$ was negative throughout the 14-day period.

Initial growth rates were significantly lower at $33{ }^{\circ} \mathrm{C}$ than at $30{ }^{\circ} \mathrm{C}$ in all strains other than D-K111 (ANOVA, Tukey's HSD test, $p<0.05$ ) (Figure 2A). The growth rate of D-K111 was not significantly lower at $33{ }^{\circ} \mathrm{C}$ than at $30{ }^{\circ} \mathrm{C}$. Strain A-Y106 had a negative initial growth rate at $33{ }^{\circ} \mathrm{C}$. The secondary (plateau) growth rates were significantly lower at $33{ }^{\circ} \mathrm{C}$ than at $30{ }^{\circ} \mathrm{C}$ in three strains $(\mathrm{B}-\mathrm{K} 100, \mathrm{C}-\mathrm{Y} 103$, and A-Y106), in which all rates were negative (Figure 2B). In strain D-K111, the secondary growth rate was higher at $33{ }^{\circ} \mathrm{C}$ than at $25^{\circ} \mathrm{C}$ or $30{ }^{\circ} \mathrm{C}$, however, cells of this strain tended to adhere to tube walls, making the cell density data unreliable. 

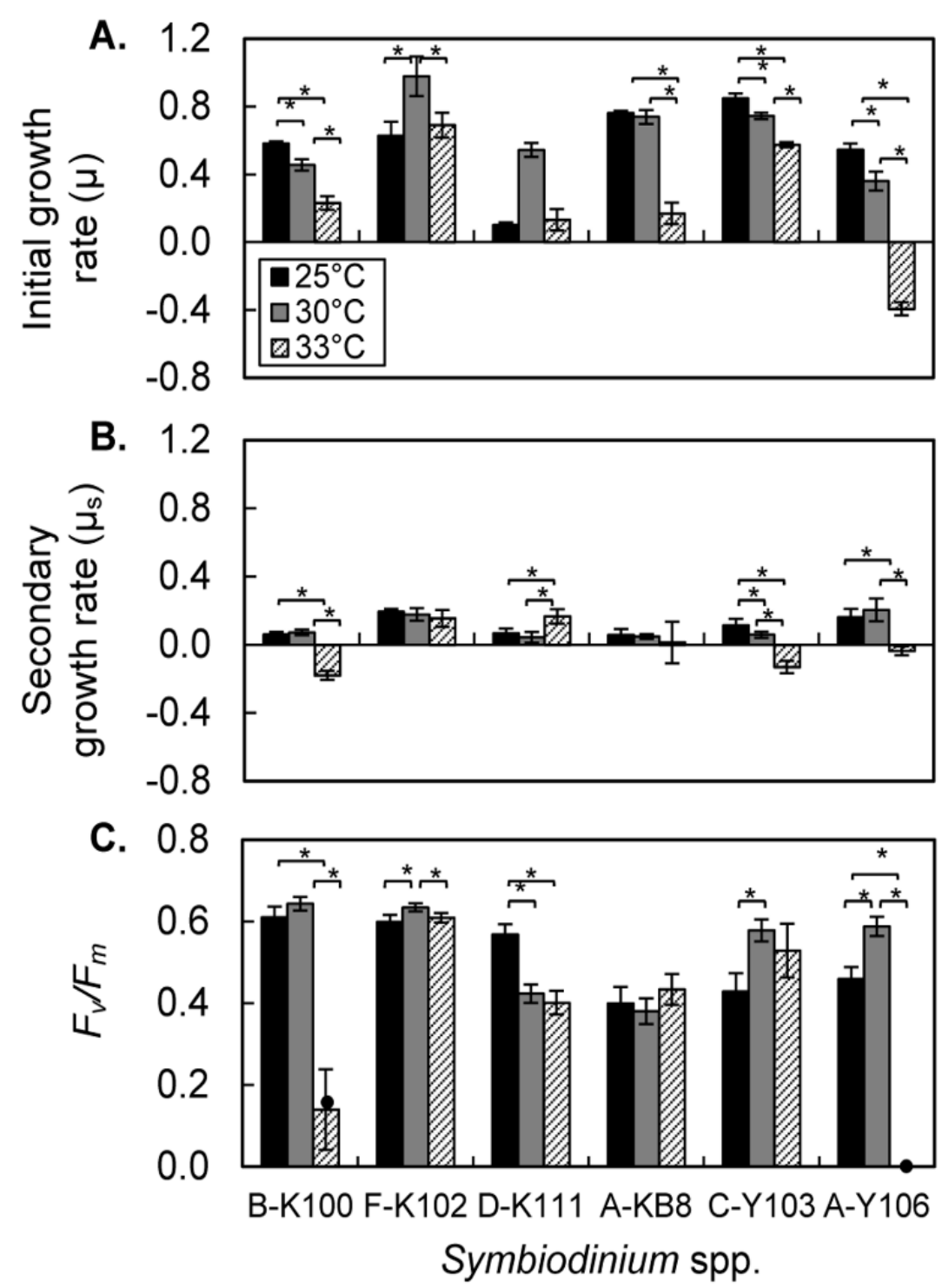

Figure 2. Growth rates and photochemical efficiencies $\left(F_{v} / F_{m}\right)$ of six strains of Symbiodinium cells. (A). Initial growth rates $(\mu)$ of cells cultured at different temperatures; (B) Secondary growth rates $\left(\mu_{\mathrm{s}}\right)$ of cells cultured at different temperatures. (C). $F_{v} / F_{m}$ measured after 14 days of temperature treatment. Filled circles in $\mathrm{C}$ indicate the $F_{v} / F_{m}$ values obtained in an additional experiment, *: significant differences between treatments (one-way ANOVA followed by Tukey's HSD tests, $p<0.05$ for all strains other than KB8; KB8 data were analyzed by non-parametric Kruskal-Wallis ANOVA followed by non-parametric multiple comparison tests, $p<0.05)$. Values are means $\pm \mathrm{SD}(n=4)$.

\subsection{Photochemical Efficiency of PSII vs. Growth Rate of Symbiodinium Cells}

Photochemical efficiencies $\left(F_{v} / F_{m}\right)$ were significantly lower at $33{ }^{\circ} \mathrm{C}$ than at $25{ }^{\circ} \mathrm{C}$ in strains B-K100, D-K111, and A-Y106 (Figure $2 \mathrm{C}$ ). However, $F_{v} / F_{m}$ values of strains F-K102, A-KB8, and C-Y103 at $33{ }^{\circ} \mathrm{C}$ were comparable to those at $25{ }^{\circ} \mathrm{C}$. The $F_{v} / F_{m}$ ratios of strains F-K102, A-KB8, C-Y103, and D-K111 remained relatively high $(0.4-0.6)$ at $33{ }^{\circ} \mathrm{C}$. 
Low cell density prevented measurements of $F_{v} / F_{m}$ in strains B-K100 and A-Y106 at $33{ }^{\circ} \mathrm{C}$; we therefore performed an additional experiment to obtain $F_{v} / F_{m}$ values (data identified by filled circles in Figure 2C). In this additional experiment, we measured the cell density and photochemical efficiency of strains B-K100, A-Y106, and C-Y103 every second day during a 12-day high temperature $\left(33^{\circ} \mathrm{C}\right)$ treatment. Cell densities exceeded $5 \times 10^{5}$ cells $\mathrm{mL}^{-1}$ in all three strains during the experimental period. $F_{v} / F_{m}$ values for C-Y103 remained high, but those for A-Y106 and B-K100 declined to zero and $<0.2$, respectively.

\subsection{Photoinhibition Experiments}

Relative $F_{v} / F_{m}$ values normalized to initial values decreased to zero or significantly after $2 \mathrm{~h}$ exposure to strong light $\left(470 \mu \mathrm{mol}\right.$ photons $\left.\mathrm{m}^{-2} \cdot \mathrm{s}^{-1}\right)$ at both $25^{\circ} \mathrm{C}$ and $33{ }^{\circ} \mathrm{C}$ in all strains (Figure 3 , ANOVA or Kruskal-Wallis, $p<0.05$ ). The decreases were greater at $33{ }^{\circ} \mathrm{C}$ than at $25{ }^{\circ} \mathrm{C}$ by $24 \%-29 \%$ of the initial values in strains F-K102, D-K111 and A-KB8 in the absence of lincomycin. Decreases in F-K102, $\mathrm{D}-\mathrm{K} 111, \mathrm{C}-\mathrm{Y} 103$ and A-KB8 at $25{ }^{\circ} \mathrm{C}$ were greater in the presence of lincomycin than in its absence by $20 \%-40 \%$ of the initial values.
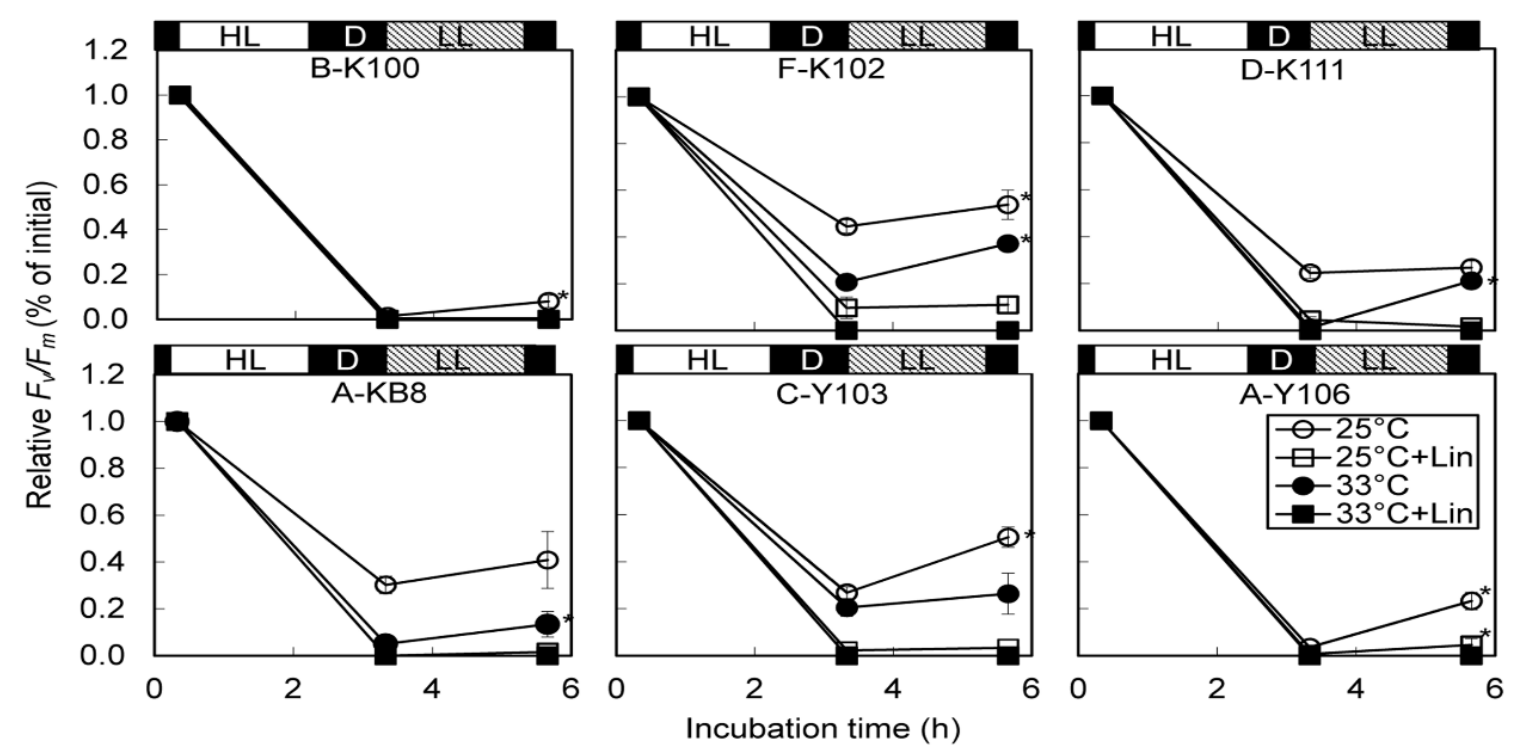

Figure 3. Photodamage and photorepair in six strains of Symbiodinium cells at 25 and $33{ }^{\circ} \mathrm{C}$. Photochemical efficiencies $\left(F_{v} / F_{m}\right)$ were measured before and after 2-h of exposure to strong light ( $\mathrm{HL}, 470 \mu \mathrm{mol}$ photons $\mathrm{m}^{-2} \cdot \mathrm{s}^{-1}$ ), and after a 2-h recovery period under dim light (LL, $20 \mu \mathrm{mol}$ photons $\mathrm{m}^{-2} \cdot \mathrm{s}^{-1}$ ) at both temperatures. Cultured Symbiodinium cells were incubated in the presence (squares) or absence (circles) of $200 \mu \mathrm{g} \mathrm{mL}^{-1}$ lincomycin at 25 (open symbols) or $33{ }^{\circ} \mathrm{C}$ (closed symbols), *: significant recovery after the strong light treatment (Tukey's HSD test, $p<0.05)$. Means \pm SD $(n=4)$.

In the absence of lincomycin, $F_{v} / F_{m}$ values of B-K100, F-K102, C-Y103, and A-Y106 significantly recovered at $25{ }^{\circ} \mathrm{C} . F_{v} / F_{m}$ values of other strains increased slightly, but not significantly after the recovery period. F-K102 was the only strain able to recover at both temperatures in the absence of lincomycin. $F_{v} / F_{m}$ values of strains D-K111 and A-KB8 recovered significantly at $33{ }^{\circ} \mathrm{C}$. When lincomycin was present, $F_{v} / F_{m}$ in all strains decreased to almost zero after strong light exposure at both $25^{\circ} \mathrm{C}$ and $33{ }^{\circ} \mathrm{C}$; however, A-Y106 significantly recovered at $25^{\circ} \mathrm{C}$. 


\section{Discussion}

\subsection{Growth rate of Symbiodinium Cells at Different Temperatures}

The growth rates of all six strains in the logarithmic phase were in the range $0.6-0.8$ at $25{ }^{\circ} \mathrm{C}$. High temperature had different effects among strains. Growth rates were significantly depressed in B-K100, A-KB8, C-Y103, and A-Y106 at $33{ }^{\circ} \mathrm{C}$. A-Y106 had a negative growth rate at $33{ }^{\circ} \mathrm{C}$. Only F-K102 had similar growth rates at $25^{\circ} \mathrm{C}$ and $33^{\circ} \mathrm{C}$.

The secondary, or stationary, growth rates were lower than rates during the initial logarithmic phase. High temperature significantly reduced the secondary growth rate of B-K100, C-Y103, and A-Y106; all of their secondary growth rates were negative at $33{ }^{\circ} \mathrm{C}$. A-KB 8 had a reduced secondary growth rate at $33{ }^{\circ} \mathrm{C}$, but the effect was not significant due to large variance in the data. Only F-K102 had similar secondary growth rates at $25{ }^{\circ} \mathrm{C}, 30{ }^{\circ} \mathrm{C}$, and $33^{\circ} \mathrm{C}$. Thus, B-K100, C-Y103, and A-Y106 were highly sensitive to high temperatures, and unable to proliferate at $33{ }^{\circ} \mathrm{C}$. A population collapse would be expected at this temperature. A-KB8 was also sensitive to high temperature, but nevertheless able to maintain cell densities at $33{ }^{\circ} \mathrm{C}$. F-K102 was highly tolerant of elevated temperature and continued growing at $33{ }^{\circ} \mathrm{C}$. The effect of high temperature on the growth rate of D-K111 differed among growth phases; however artifacts caused by cell adherence to culture tube walls introduced a considerable degree of uncertainty in ascertaining temperature responses of this strain. In our preliminary study, we counted the number of adhered cells and those in suspension after 21 days exposure to different temperatures. We found that the percentage of adhered cells was highest in D-K111. Furthermore, high temperature increased the percentage of adhered cells in high temperature-sensitive strains (B-K100 and A-Y106). Improved method should be applied to estimate growth response of strains with tendency to adhere to culture tube walls [24]

The four-day duration of the logarithmic phase in this study was relatively short. This might be partly due to a relatively high initial cell density used in this study. An initial reduction in cell densities after cell inoculation into the culture vessels occurred in all strains other than A-KB8. This reduction may be explained in part by the adhesion of some cells to the culture tube walls and in part by the initial lag phase before cells entered the logarithmic phase, as reported previously for green algae [28].

\subsection{Photochemical Efficiency of PSII after High Temperature Treatment}

Photochemical efficiencies $\left(F_{v} / F_{m}\right)$ of B-K100 and A-Y106 were significantly depressed at high temperature $\left(33{ }^{\circ} \mathrm{C}\right)$ in comparison with efficiencies at $25{ }^{\circ} \mathrm{C} . F_{v} / F_{m}$ values of D-K111 were also significantly reduced at $33^{\circ} \mathrm{C}$, although the ratio (ca. 0.4) was, nevertheless, relatively high. $F_{v} / F_{m}$ values of F-K102, A-KB8, and C-Y 103 were similar at $25{ }^{\circ} \mathrm{C}$ and $33{ }^{\circ} \mathrm{C}$.

Table 1 shows the effects of temperature on the initial growth rates, secondary growth rates, and $F_{v} / F_{m}$ ratios for each of the strains. A-Y106 was the most sensitive to high temperature stress: both initial and secondary growth rates were negative, and $F_{v} / F_{m}$ decreased to zero after 10 -days of exposure to $33{ }^{\circ} \mathrm{C}$. B-K100 was the next most sensitive to thermal stress; it had a negative secondary growth rate and a marked reduction in $F_{v} / F_{m}$ at $33{ }^{\circ} \mathrm{C}$. A-KB8 and C-Y103 were notably different from other strains; their secondary growth rates became negative even though $F_{v} / F_{m}$ values remained high. Strain F-K102 was the most tolerant of thermal stress; it had the highest $F_{v} / F_{m}$ ratio and initial growth rate at $30{ }^{\circ} \mathrm{C}$. The 
$F_{v} / F_{m}$ values and secondary growth rates of this strain were closely similar at $33^{\circ} \mathrm{C}$ and $25^{\circ} \mathrm{C}$. D-K 111 was tolerant of thermal stress: it retained a high $F_{v} / F_{m}$ values at $33{ }^{\circ} \mathrm{C}$ and it secondary growth rate at this temperature was significantly higher than those at $25{ }^{\circ} \mathrm{C}$ or $30{ }^{\circ} \mathrm{C}$. However, the tendency of D-K111 cells to adhere to the wall of the tubes confounded measurements of cell density by the in vivo fluorescence method used in this study. Thus, the six strains of Symbiodinium fell into three categories: (1) growth responses and photochemical efficiencies were highly sensitive to high temperature (B-K100 and A-Y106), (2) the growth responses were highly sensitive to high temperature but photochemical efficiencies were not (C-Y103 and A-KB8), (3) growth responses and photochemical efficiencies were both highly tolerant of elevated temperature (F-K102 and D-K111).

Table 1. Effects of temperature on the initial growth rate, secondary growth rate, and $F_{v} / F_{m}$ of the Symbiodinium strains. Conditions under which significant recovery from photodamage was observed are also shown.

\begin{tabular}{|c|c|c|c|c|c|}
\hline Symbiodinium strain & Initial growth rate $(\mu)$ & Secondary growth rate $\left(\mu_{s}\right)$ & $\mathbf{F}_{\mathrm{v}} / \mathbf{F}_{\mathrm{m}}$ & Recovery & Category \\
\hline $\begin{array}{l}\text { B-K100 } \\
\text { (clade B) }\end{array}$ & $25^{\circ} \mathrm{C}>30^{\circ} \mathrm{C}>33^{\circ} \mathrm{C}$ & $25^{\circ} \mathrm{C}=30^{\circ} \mathrm{C}>33^{\circ} \mathrm{C}$ & $25^{\circ} \mathrm{C}=30^{\circ} \mathrm{C}>33^{\circ} \mathrm{C}$ & $*\left(25^{\circ} \mathrm{C}\right)$ & \multirow{2}{*}{ heat-sensitive } \\
\hline $\begin{array}{l}\text { A-Y106 } \\
\text { (clade A) }\end{array}$ & $25^{\circ} \mathrm{C}>30^{\circ} \mathrm{C}>33^{\circ} \mathrm{C}$ & $25^{\circ} \mathrm{C}=30^{\circ} \mathrm{C}>33^{\circ} \mathrm{C}$ & $25^{\circ} \mathrm{C}<30{ }^{\circ} \mathrm{C}>33^{\circ} \mathrm{C}$ & $\left.*\left(25^{\circ} \mathrm{C}\right), 25^{\circ} \mathrm{C}(+\operatorname{Lin})\right)$ & \\
\hline $\begin{array}{l}\text { A-KB8 } \\
\text { (clade A) }\end{array}$ & $25^{\circ} \mathrm{C}=30^{\circ} \mathrm{C}>33^{\circ} \mathrm{C}$ & $25^{\circ} \mathrm{C}>30^{\circ} \mathrm{C}>33^{\circ} \mathrm{C}$ & $25^{\circ} \mathrm{C}=30^{\circ} \mathrm{C}=33^{\circ} \mathrm{C}$ & $*\left(33^{\circ} \mathrm{C}\right)$ & \multirow{2}{*}{$\begin{array}{c}\text { uncoupling of } \\
\text { growth and } \mathrm{F}_{\mathrm{v}} / \mathrm{F}_{\mathrm{m}}\end{array}$} \\
\hline $\begin{array}{l}\text { C-Y103 } \\
\text { (clade C) }\end{array}$ & $25^{\circ} \mathrm{C}>30^{\circ} \mathrm{C}>33^{\circ} \mathrm{C}$ & $25^{\circ} \mathrm{C}>30^{\circ} \mathrm{C}>33^{\circ} \mathrm{C}$ & $25^{\circ} \mathrm{C}<30{ }^{\circ} \mathrm{C}=33^{\circ} \mathrm{C}$ & $*\left(25^{\circ} \mathrm{C}\right)$ & \\
\hline $\begin{array}{l}\text { F-K102 } \\
\text { (clade F) }\end{array}$ & $25^{\circ} \mathrm{C}<30^{\circ} \mathrm{C}>33^{\circ} \mathrm{C}$ & $25^{\circ} \mathrm{C}=30^{\circ} \mathrm{C}=33^{\circ} \mathrm{C}$ & $25^{\circ} \mathrm{C}<30^{\circ} \mathrm{C}>33^{\circ} \mathrm{C}$ & $*\left(25^{\circ} \mathrm{C}, 33^{\circ} \mathrm{C}\right)$ & heat-tolerant \\
\hline $\begin{array}{l}\text { D-K111 } \\
\text { (clade D) }\end{array}$ & $25^{\circ} \mathrm{C}=30^{\circ} \mathrm{C}=33^{\circ} \mathrm{C}$ & $25^{\circ} \mathrm{C}=30^{\circ} \mathrm{C}<33^{\circ} \mathrm{C}$ & $25^{\circ} \mathrm{C}>30^{\circ} \mathrm{C}=33^{\circ} \mathrm{C}$ & $*\left(33^{\circ} \mathrm{C}\right)$ & heat-tolerant \\
\hline
\end{tabular}

Inequality signs indicate significant difference between temperature treatments. Equality signs indicate no significant difference in the parameter. *: significant recovery was observed at the temperature.

Category 2 is unique in that growth responses and PSII activities were uncoupled. Robison and Warner [8] and Krämer et al. [24] also reported such uncoupling in Symbiodinium strain A1. It is possible that these strains may allocate more energy to repairing damaged PSII mechanisms (resynthesizing protein D1 and other thylakoid proteins) and antioxidant defense mechanisms than to cell proliferation. The repair of damaged PSII is a costly process compared to other photo-protective mechanisms, such as thermal dissipation through NPQ. Such allocations to repair processes may therefore reduce growth rates. It is also possible that metabolic pathways other than the photosynthetic mechanism are affected by elevated temperatures in these strains such as fatty acid composition [29] and reduction of motility [30]. These possibilities await further investigation. We should also note that the photochemical efficiency of PSII can remain high even when there is a significant decline in PSII protein content under thermal stress [31]. Although category 2 Symbiodinium cells in this study were derived from hosts other than corals, A1 Symbiodinium isolated from the coral Stylophora pistillata also shows similar uncoupling [24]. It is important to investigate how this uncoupling between algal growth and PSII activity affects susceptibility of corals to thermal stress. 


\subsection{Recovery of Photodamage of PSII}

A significant decline of relative $F_{v} / F_{m}$ was observed after 2-h exposure to high light. However, the extent of photodamage differed among Symbiodinium types. Declines at $33{ }^{\circ} \mathrm{C}$ were more marked than those at $25^{\circ} \mathrm{C}$, indicating that high temperature exacerbated photodamage. Lincomycin also exacerbated photodamage and reduced recovery of PSII function.

$F_{v} / F_{m}$ values of B-K100 and A-Y106 decreased to almost zero after $2 \mathrm{~h}$ of high light treatment; no recovery occurred at $33{ }^{\circ} \mathrm{C}$. The extremely low growth rates of B-K100 and A-Y106 at elevated temperatures might have been due to severe thermal damage to PSII. An inability to resynthesize D1 protein during stress treatment or recovery at $33{ }^{\circ} \mathrm{C}$ is the most probable explanation. F-K102 had relatively high $F_{v} / F_{m}$ values after strong light treatment and significant lincomycin-sensitive recovery at both $25^{\circ} \mathrm{C}$ and $33{ }^{\circ} \mathrm{C}$. An elevated capacity for repairing thylakoid proteins is likely related to the high thermal tolerance of this strain. The high growth rate in F-K102 at elevated temperature may be indicative of an enhanced capacity to replace damaged-D1 protein during thermal and light stresses.

Growth rate and photochemical efficiency were uncoupled in A-KB8 and C-Y103, and their high photochemical efficiencies at elevated temperatures may be attributable to highly efficient re-synthesis of D1 and other thylakoid proteins at high temperature. If this were the case, these strains may reallocate energy from growth to the repair of damaged photosynthetic machineries or protection pathways, as suggested by Robison and Warner [8] and Krämer et al. [24]. In contrast, recoveries of photodamaged PSII at $33{ }^{\circ} \mathrm{C}$ were modest in strains A-KB8 and C-Y103. Thus, thermal stressing of other metabolic pathways may have reduced growth rates in these two strains. This possibility should be explored in future research efforts.

\section{Conclusions}

In conclusion, six strains of Symbiodinium fell into three categories: (1) growth responses and photochemical efficiencies were highly sensitive to high temperature (B-K100 and A-Y106); (2) growth responses were highly sensitive to high temperature but photochemical efficiencies were not (C-Y103 and A-KB8); (3) growth responses and photochemical efficiencies were both highly tolerant of elevated temperature (F-K102 and D-K111). Artifactual adhesion of D-K111 cells to culture tube walls confounded measurements made on this strain. Strains with reduced growth rate and slightly depressed photochemical efficiency may be useful models for future research into different stress susceptibilities among diverse phylotypes of Symbiodinium.

\section{Acknowledgments}

We thank four anonymous reviewers for constructive comments on the manuscript. This work was supported by the International Research Hub Project for Climate Change and Coral Reef/Island Dynamics and Strategic Research Promotion Grant of University of the Ryukyus. 


\section{Author Contributions}

W.K. and M.H. conceived and designed the experiments. W.K. carried out the experiments and S.N. helped Symbiodinium clade identification. W.K. and M.H. drafted the manuscript. All authors read and approved the final manuscript.

\section{Conflicts of Interest}

The authors declare no conflict of interest.

\section{References}

1. Davies, P.S. The role of zooxanthellae in the nutritional energy requirements of Pocillopora eydouxi. Coral Reefs 1984, 2, 181-186.

2. Muscatine, L. The role of symbiotic algae in carbon and energy flux in reef corals. Ecosyst. World 1990, 25, 75-87.

3. Fitt, W.K.; Brown, B.E.; Warner, M.E.; Dunne, R.P. Coral bleaching: Interpretation of thermal tolerance limits and thermal thresholds in tropical corals. Coral Reefs 2001, 20, 51-65.

4. Lesser, M.P. Coral Bleaching: Causes and Mechanisms. In Coral Reefs: An Ecosystem in Transition; Springer: The Netherlands, 2011; pp. 405-419.

5. Weis, V.M. Cellular mechanisms of Cnidarian bleaching: Stress causes the collapse of symbiosis. J. Exp. Biol. 2008, 211, 3059-3066.

6. Roth, M.S. The engine of the reef: Photobiology of the coral-algal symbiosis. Front. Microbiol. 2014, 5, 422.

7. Tchernov, D.; Gorbunov, M.Y.; de Vargas, C.; Yadav, S.N.; Milligan, A.J.; Häggblom, M.; Falkowski, P.G. Membrane lipids of symbiotic algae are diagnostic of sensitivity to thermal bleaching in corals. Proc. Natl. Acad. Sci. USA 2004, 101, 13531-13535.

8. Robison, J.D.; Warner, M.E. Differential impacts of photoacclimation and thermal stress on the photobiology of four different phylotypes of Symbiodinium (Pyrrhophyta). J. Phycol. 2006, 42, 568-579.

9. Takahashi, S.; Whitney, S.; Itoh, S.; Maruyama, T.; Badger, M. Heat stress causes inhibition of the de novo synthesis of antenna proteins and photobleaching in cultured Symbiodinium. PNAS 2008, 105, 4203-4208.

10. Takahashi, S.; Whitney, S.M.; Badger, M.R. Different thermal sensitivity of the repair of photodamaged photosynthetic machinery in cultured Symbiodinium species. Proc. Natl. Acad. Sci. USA 2009, 106, 3237-3242.

11. Karim, W.; Seidi, A.; Hill, R.; Chow, W.S.; Minagawa, J.; Hidaka, M.; Takahashi, S. Novel characteristics of photodamage to photosystem II in a high-light-sensitive Symbiodinium phylotype. Plant Cell Physiol. 2015, doi:10.1093/pcp/pcv040.

12. Saragosti, E.; Tchernov, D.; Katsir, A.; Shaked, Y. Extracellular production and degradation of superoxide in the coral Stylophora pistillata and cultured Symbiodinium. PLoS ONE 2010, 5, e12508. 
13. McGinty, E.S.; Pieczonka, J.; Mydlarz, L.D. Variations in reactive oxygen release and antioxidant activity in multiple Symbiodinium types in response to elevated temperature. Microb. Ecol. 2012, 64, 1000-1007.

14. Krueger, T.; Becker, S.; Pontasch, S.; Dove, S.; Hoegh-Guldberg, O.; Leggat, W.; Fisher, P.L; Davy, S.K. Antioxidant plasticity and thermal sensitivity in four types of Symbiodinium sp. J. Phycol. 2014, 50, 1035-1047.

15. Bhagooli, R.; Hidaka, M. Comparison of stress susceptibility of in hospite and isolated zooxanthellae among five coral species. J. Exp. Mar. Biol. Ecol. 2003, 291, 181-197.

16. Baird, A.H.; Bhagooli, R.; Ralph, P.J.; Takahashi, S. Coral bleaching: The role of the host. Trends Ecol. Evol. 2009, 24, 16-20.

17. Lesser, M.P. Elevated temperatures and ultraviolet radiation cause oxidative stress and inhibit photosynthesis in symbiotic dinoflagellates. Limnol. Oceanogr. 1996, 41, 271-283.

18. Warner, M.E.; Fitt, W.K.; Schmidt, G.W. The effects of elevated temperature on the photosynthetic efficiency of zooxanthellae in hospite from four different species of reef coral: A novel approach. Plant Cell Environ. 1996, 19, 291-299.

19. Warner, M.E.; Fitt, W.K.; Schmidt, G.W. Damage to photosystem II in symbiotic dinoflagellates: A determinant of coral bleaching. PNAS 1999, 96, 8007-8012.

20. Lilley, R.; Ralph, P.J.; Larkum, A.W. The determination of activity of the enzyme Rubisco in cell extracts of the dinoflagellate alga Symbiodinium sp. by manganese chemiluminescence and its response to short-term thermal stress of the alga. Plant Cell Environ. 2010, 33, 995-1004.

21. Hill, R.; Szabó, M.; ur Rehman, A.; Vass, I.; Ralph, P.J.; Larkum, A.W. Inhibition of photosynthetic $\mathrm{CO}_{2}$ fixation in the coral Pocillopora damicornis and its relationship to thermal bleaching. J. Exp. Biol. 2014, 217, 2150-2162.

22. Ragni, M.; Airs, R.L.; Hennige, S.J.; Suggett, D.J.; Warner, M.E.; Geider, R.J. PSII photoinhibition and photorepair in Symbiodinium (Pyrrhophyta) differs between thermally tolerant and sensitive phylotypes. Mar. Ecol. Prog. Ser. 2010, 406, 57-70.

23. Jeans, J.; Campbell, D.A.; Hoogenboom, M.O. Increased reliance upon photosystem II repair following acclimation to high-light by coral-dinoflagellate symbioses. Photosyn. Res. 2013, 118, 219-229.

24. Krämer, W.E.; Caamaño-Ricken, I.; Richter, C.; Bischof, K. Dynamic regulation of photoprotection determines thermal tolerance of two phylotypes of Symbiodinium clade A at two photon fluence rates. Photochem. Photobiol. 2012, 88, 398-413.

25. Wood, A.M.; Everroad, R.C.; Wingard, L.M. Measuring growth rates in microalgal cultures. In Algal Culturing Techniques, Andersen, R.A., Ed.; Elsevier Academic Press: Burlington, MA, USA, 2005; pp. 269-286.

26. Maxwell, K.; Johnson, G.N. Chlorophyll fluorescence-a practical guide. J. Exp. Bot. 2000, 51, 659-668.

27. Hennige, S.J.; McGinley, M.P.; Grottoli, A.G.; Warner, M.E. Photoinhibition of Symbiodinium spp. within the reef corals Montastraea faveolata and Porites astreoides: Implications for coral bleaching. Mar. Biol. 2011, 158, 2515-2526.

28. Xin, L.; Hong-Ying, H.; Yu-Ping, Z. Growth and lipid accumulation properties of a freshwater microalga Scenedesmus sp. under different cultivation temperature. Bioresour. Technol. 2011, 102, 3098-3102. 
29. Díaz-Almeyda, E.; Thomé, P.E.; El Hafidi, M.; Iglesias-Prieto, R. Differential stability of photosynthetic membranes and fatty acid composition at elevated temperature in Symbiodinium. Coral Reefs 2011, 30, 217-225.

30. Nitschke, M.R.; Davy, S.K.; Cribb, T.H.; Ward, S. The effect of elevated temperature and substrate on free-living Symbiodinium cultures. Coral Reefs 2015, 34, 161-171.

31. Jeans, J.; Szabo, M.; Campbell, D.A.; Larkum, A.W.D.; Ralph, P.J.; Hill, R. Thermal bleaching induced changes in photosystem II function not reflected by changes in photosystem II protein content of Stylophora pistillata. Coral Reefs 2014, 33, 131-139.

(C) 2015 by the authors; licensee MDPI, Basel, Switzerland. This article is an open access article distributed under the terms and conditions of the Creative Commons Attribution license (http://creativecommons.org/licenses/by/4.0/). 